\title{
Narratives of Kingship in Fictional Literature*
}

\author{
Richardvan Leeuwen
}

In the previous chapters several significant aspects of kingship and courtly structures in the Eurasian empires were discussed, focusing on court politics and court culture, religion, military organization, manuals of statecraft, and dynastic reproduction. In this final chapter we will direct our attention to more abstract and volatile issues, which were nevertheless essential for the functioning of royal authority and the institution of kingship: the embedding of kingship, as a historical, cultural, and political phenomenon, in discourses of power. Evidently, claims to kingship had to be legitimized first of all in the political and legal discourses that reflected, and constructed, power configurations that became institutionalized within specific political systems and contexts. These ideological underpinnings were crucial for the functioning of the state and the preservation and stabilization of dynastic rule. Authority was formally anchored in the institution of kingship and acknowledged by the groups in power.

Although these formal aspects of ideological discourse are required for establishing structures of authority, they reveal only its 'official' component. Apart from formal, political elements, discourses of power often contain what may be called an 'aesthetic' or cultural component as well. This consists of all manifestations of kingship in the realm of culture and its social embedding, such as celebrations and ritual, architectural and artistic styles, court ceremony, representations and images, etc. All these phenomena not only tended to strengthen the presence of the king within his court and in society; they also provided a medium for converging claims to kingship and the domain of the imagination. Through the cultivation of the aesthetic components of discourses of kingship, royal power was displayed and transformed, to facilitate its incorporation into social life in a specific way and, more structurally, into the collective imagination.

The aesthetic elements of discourses of power thus seem intended to bridge the gap between the king and the populace, between groups in power and the

\footnotetext{
* This chapter contains a brief summary of the monograph: Richard van Leeuwen, Narratives of Kingship in Eurasian Empires 1300-1800 (Leiden, 2017).
} 
common people, between a closed political segment and society as a whole. This is not to say, that they reflect a 'popular' form of discourse as opposed to formal, courtly discourses. The aesthetic components were certainly shaped to a large extent by the tastes and interests of ruling elites. Still, they allowed those in power to connect with cultural traditions and legacies that strengthened their roots in society and that incorporated notions of cultural identification, historical continuity, and values and images stored in popular culture. They were aimed at mutual acknowledgement, strengthening ties that could be expressed not only by the mere exertion of power or by formal claims. They reflected the connection between the king and his subjects, and transformed his formal power into a more widely accepted form of authority. Kings could use their power to structure and foster visions of their kingship by linking it to specific components already present in the collective imagination and the cultural tradition.

In this chapter we will concentrate on a specific domain of the aesthetic component of discourses of kingship, that is the corpus of fictional narratives. The aim is to investigate how these narratives reflect the ways in which discourses of kingship were incorporated, explicated, preserved, and transmitted through the medium of literature, as a container of both popular imaginings of kingship and political and ethical claims to royal power. This rather ambitious intention immediately raises a number of questions that are partly related to the historical context, which is both geographically and temporally enormous, and partly to the corpus of texts, which is not only vast but also notoriously fluid and volatile. Moreover, it is evidently not even remotely possible to present a more or less complete survey, and it is inevitable to formulate a number of important caveats. In the limited space of this chapter we will be able to discuss only a relatively small number of examples, which, moreover, are available in English, German, or French translations. ${ }^{1}$

Among the problems involved in this kind of research is the question of how to demarcate and justify the corpus. To what extent do the selected texts represent the interface between elite and popular discourses? To what extent can they be considered as 'fictional' texts, taking the contemporary context into account with its potentially different views of fictionality? To what extent can the chosen texts be linked to specific cultural and political realms, and to what extent were they shaped by these historical contexts? To what extent can similarities and commonalities be attributed to direct mutual influence,

1 For a more elaborated discussion of the limitations, criteria, and theoretical aspects of the research project see the Introduction in Van Leeuwen, Narratives of Kingship. 
trajectories of migration and translation, common sources, common narrative conventions? There is no space here to elaborate on these questions. May it suffice to say that, in general, literary and cultural trajectories were not always congruent with the rise and fragmentation of political structures and had their own, dynamic realm. Partly because of their fluidity, it is difficult, often even impossible, to securely link cultural and literary tendencies to historical contexts and to determine clear patterns of influence and transmission. This part of the research must therefore necessarily remain speculative.

The texts that have been selected are marked, first of all, by forms of hybridity in various respects. They are mostly situated in the area between 'official' and 'popular' discourses, reflecting popular traditions of storytelling, but also emphasizing the significance of authority, hierarchies, social order, and stability. Since they were preserved mainly or partly in the layer of popular tradition, they have often survived in various versions and adaptations, covering large stretches of time, and reflecting not only influences of historical change, but also of historical continuity, conveying cultural trends and motifs from the past to the future. Moreover, they often straddle the area of fiction and non-fiction, either combining the two modes within single narratives, or fictionalizing history or instructive, explanatory treatises. Finally, they are often part of different linguistic domains and as such reveal traces of local contexts and circumstances, but also contain more universal notions, relating to issues of power, kingship, and morality. The hybridity of the texts emphasizes their essential fluidity and their function as media meant to integrate discourses of power into the more persistent heritage of the collective imagination.

The narratives selected for this chapter belong to the genres of, roughly, the mirror for princes, the romance of chivalry, the (historical) novel, and the love romance. In each of the following sections two main texts have been chosen from the various domains (Chinese, Indian, Persian/Arabic, European) exemplifying either the relevant characteristics of their genre and/or the argument we want to make here, that is, their function in the construction of narratives of kingship. Each section focuses on one of the main themes, which are the 'composite' nature of the figure of the king, reflected in his relationship with his minister or his wife; the role of, particularly religious, initiation; the legitimizing role of history with its inherent moral values; and the role of women as a major factor in the disruption and continuation of dynasties. We will concentrate not only on portrayals of kingship and its paraphernalia and connotations, but also on textual and narrative strategies. Needless to say, in the space of this chapter these aspects can be referred to only in summary fashion. 
In the Islamic traditions mirrors for princes belonged to the oldest generic forms, probably inherited from more ancient prototypes in Persian and Sanskrit literature. In several respects, the brief text called the 'Seven viziers' can serve as a prototype here, not only exemplifying the genre of the mirror for princes, but also displaying several features of the discourse of statecraft as it evolved within Islamic literature. The narrative is preserved in Arabic and Persian versions from the thirteenth to fourteenth centuries and was translated into several European languages, under various titles. The form of the narrative follows the model of the Persian mirror for princes, such as Kalila wa-Dimna, consisting of a framing story, which contains the narrative intrigue, but which also determines the level of narrative reality, and a series of embedded tales, which serve as exemplary tales to support and interact with the intrigue in the frame. ${ }^{2}$

The story of the frame is briefly as follows: in response to a prophecy, a prince who has just reached majority is not allowed to speak for seven days, or else harm will befall him. To protect him, he is lodged in the women's compound, but one of the king's concubines conceives an evil scheme: she tries to seduce him into murdering his father, usurping the throne, and marrying her. When the prince refuses to concede, she accuses him of having assaulted her. The king, infuriated, commands the execution of his son, but now the viziers intervene. To avert, or at least postpone, the execution, they start telling exemplary stories, alternating with the stories told by the concubine to support her case. After seven days have passed, the prince is allowed to speak and give his version of the events. Now the truth is revealed; the concubine is punished and the prince is educated in preparation for his accession to the throne. The prince and the empire are saved, due to the resourceful intervention of the viziers.

The rather concise narrative intrigue of the 'Seven viziers' cycle hides a complex and interesting vision of power and authority. Some of the aspects associated with kingship, such as the education of the prince and the role of women will be discussed in later sections below. What interests us here is particularly the nature of the relationship between the king and his viziers. It is noteworthy that it is not the all-powerful king who solves the problem

2 Zahiri de Samarkand, Le livre des sept vizirs, trans. Dejan Bogdanovic (Paris, 1975); see also: Killis Campbell, The Seven Sages of Rome, Edited from the Manuscripts, with Introduction, Notes, and Glossary (Forgotten Books, 2012 [Boston etc., 1907]); and: Ulrich Marzolph and Richard van Leeuwen, eds., The Arabian Nights Encyclopedia, 2 vols. (Santa Barbara, 2003). 
of the rebellious concubine and by doing so saves the dynasty, but rather the viziers, who succeed in preventing his rash decision and in restoring the sway of moderation and careful consideration by referring to the wisdom conveyed in tales and the crucial significance of rationality. The vicious concubine attempts to intervene in the process of dynastic succession not only by reconceiving the procedures, but also by an appeal to the senses and emotions, first of the prince, and subsequently of the king. After failing to seduce the prince, she appears before the king as the victim of injustice, weeping and wailing, with dishevelled hair and torn clothes.

At first the king seems to fall into her trap and to abandon proper procedures and give in to his emotional impulses. This response seems to contradict his solemn position as a sovereign, but in fact it is consistent with the complexity of his role. The king is primarily a man and the head of his household. If a conflict emerges within his household, he is bound to react fiercely and with authority because it touches upon his personal and emotional welfare. But as a king, too, a violent response is justified. His power, as a mighty monarch, is based on his ability and privilege to use violence in an arbitrary way or at least to threaten with it. His indignation is not only justified, but also required because it supports his power as a king. Still, as a king, he is also the personification of an institution that is sanctioned by dynastic privileges, legal and historical legitimacy, and the heritage of the tradition of wisdom and statecraft. Therefore, the king incorporates several layers of power, which he in one way or another has to mutually reconcile.

The intrigue thus lays bare the various personae of the king and thereby reveals the complex, composite nature of kingship. Kingship is not monolithic nor merely a confluence of all-encompassing powers; it rather consists of a balance between various different, and sometimes contradictory, roles. It is the viziers who are responsible for preserving the balance between these roles and for taking care that the personal and emotional aspects do not prevail and are neutralized by an appeal to wisdom, tradition, and sound judgement. It is the privilege, even the duty, of the king to respond impulsively in certain situations and thereby show his might; it is the task of the viziers to mitigate the disruptive effects of this emotionality and turn it into a source of stability and continuity. It is their task to transform the sheer power of the king into authority and thereby secure the continuity of kingship as an institution.

It is no coincidence that the narrative intrigue revolves around the approaching transfer of royal authority to the next generation. It is at this point that the dynasty is at its most vulnerable and the empire is threatened by its greatest danger, disruption and chaos. The narrative intrigue reveals the hidden nature of kingship, its essential compositeness, and necessitates the unravel- 
ling of its basic principles. These principles are recapitulated within a process of storytelling by the viziers, installing a situation of dialogue not only between the concubine and the viziers, but more importantly between the viziers and the king. This situation illustrates the essentially dialogic nature of kingship as an institution, between the protagonist of power and the protagonists of tradition and wisdom. Moreover, the dialogic exchange results in a systematic explication of the principles of governance, which not only serves to educate the prince, but also, ultimately, to instruct the reader, in order to instil in him the acceptance of rational, institutionalized rule.

The tension between the different personae of the king and the prominent role of the viziers can be found in several narratives related to the 'Seven viziers'. A notable variation on the same theme is the Persian/Arabic story of 'King Jali'ad of Hind, and his son Wirdkhan', in which the young king Wirdkhan indulges in his carnal lusts and rules according to the advice of his women, even to the extent of killing his brilliant vizier Shimas. Here, too, the narrative intrigue contains a compendium of the rules of statecraft, which in the end averts disaster and ensures the harmonization of the different components of kingship. ${ }^{3}$ But in other traditions, too, we find similar motifs. The tension between the various components of kingship seems especially relevant for the Chinese tradition, where the emperor is part of a huge constellation of cosmic forces. In the Chinese tradition, generally speaking, the situation of the empire is dependent on the balance of the forces of Yang and Yin, which reflects the unfolding of destiny through a continuing struggle of forces both on earth and in the celestial realms. The institutionalization of kingship is therefore vested not only in earthly traditions, but also in the celestial 'institutions', which have their own dynamics but are in constant interaction with actors on earth.

The Chinese notion of kingship is therefore a curious dualism of earthly and celestial forces, and of destiny and personal intervention. On the one hand, the emperor is only the cornerstone of the configuration of cosmic forces as it is shaped by destiny; on the other hand, he personally embodies this configuration in his character and actions. The government, as an institutionalized system, is also determined by these forces, but as a system it is objectified as much as possible, that is, it should be autonomous in its functioning according to rules, hierarchies, and procedures. The emperor should guard the functioning of the state apparatus, but the mechanism should be based exclusively on

3 The story of 'King Jali'ad and his son, Wirdkhan': The Arabian Nights: Tales of 1001 Nights, trans. Malcolm C. Lyons and Ursula Lyons, 3 vols. (London etc., 2008) vol. 3; see also Marzolph and van Leeuwen, Arabian Nights Encyclopedia. 
formalized procedures, circumscribed tasks, and written evaluations. It is the objectification of the system of government that should ensure the stability and preservation of the empire, but, inevitably, the failure of either the king or his officials to fulfil their duties according to the prescriptions will herald a major catastrophe. This is, of course, rich material for storytelling.

An interesting text whose intrigue revolves around the tensions caused by a lascivious emperor and a disloyal minister is Proclaiming harmony, a vernacular novel written probably in the fourteenth century. The story refers to the historical events leading to the fall of the Northern Song dynasty and the invasion of the Mongolian Jurchen tribes in the years 1069-1124. ${ }^{4}$ The novel opens with some general statements about the forces of Yin and Yang, which determine the course of history. If Yang is dominant, China will be peaceful, the ruler will be enlightened, and the empire will be fertile; if Yin is in the ascendant, the tribes will invade, selfish men will be appointed, and starvation and discord will reign. This alternation of Yin and Yang depends on the conduct of one man, the emperor. After this introduction, ominously, the devious Wang Anshi is appointed as Grand Counsellor. He immediately starts conspiring and scheming, undermining the proper functioning of the state.

The young emperor Huizong is talented, but inclined to trifling amusements and sensual pleasures, neglecting state affairs. One day, on the instigation of his evil ministers, the emperor is persuaded to undertake a licentious escapade in the less reputable quarters of the city. He promptly falls in love with a beautiful courtesan, whom he has moved to the palace. He even lets her sit on the throne next to him. This is the beginning of a series of events that eventually lead to the invasion of the Jurchen, the fall of the capital, and the end of the dynasty. It was the spurned empress who predicted the fatal outcome: 'The three bonds of family and the five constant virtues are being dragged to the ground. When men have a sense of decorum they are strong; having it not, they are destroyed. ${ }^{5}$ When personal misbehaviour disturbs the mechanisms of government, the system collapses. The ministers are ambitious and corrupt, the capital is conquered, and the dynastic documents are stolen. The imperial family is abducted ignominiously to the north by the "barbarians'.

The fall of the dynasty was here caused by the fatal coincidence of a negligent emperor and a vicious minister, corrupting an essentially ideal system

4 See for the historical context of these events F.W. Mote, Imperial China 900-180o (Cambridge and London, 2003).

5 Proclaiming Harmony, trans. William O'Hennesy (Ann Arbor, 1991) 79. 
of government. The story indicates the dialogic nature of kingship by staging several loyal and righteous viziers, who attempt to ward off the catastrophe. Quoted verbatim in the text are several memorials of ministers, protesting against the destructive policy of the prime minister and summoning the emperor to mend his ways. They point out that it is the task of the ministers to admonish the emperor: 'Mencius has said: "One whose responsibility it is to give advice should resign if he is unable to give it, even if it meant discountenancing the emperor."' 6 Here, as in the 'Seven viziers', it is the ministers who have to remind the emperor of the wisdom of the ancient tradition, which contains the principles of just and virtuous rule. They represent the 'conscience' of the emperor, protecting him from his baser instincts and summoning him to heed the principles of the institution of kingship.

In several respects the cycle of the 'Seven viziers' and the novel Proclaiming harmony exemplify themes, motifs, and narrative strategies that will recur in our discussion of discourses of kingship in other genres. First, and most importantly, they indicate that kingship is not monolithic, consisting of arbitrary power concentrated in a single person. On the contrary, kingship consists of various components, which combine personal, human inclinations with the requirements of the institutionalized order. The balance between these components is secured through a process of dialogue, primarily between the king and his ministers, the king alternating between his different roles, while the ministers attempt to accommodate his actions to the principles of traditional wisdom and proper rule. The king, as a person, has to conform ultimately to the institution of kingship, and it is the responsibility of the ministers to remind him of this.

Second, the king is the personification of the moral integrity of his kingdom. If he is morally corrupt, the balance of forces is tilted, and society, too, will lose its virtues. The moral integrity of the king is presented as the ability to reconcile his emotions with rational judgement; the ability to resist the attractions (and concomitant ruses) of women; and the adherence to the established traditions that secure the stability and continuation of the dynasty.

Third, the stories are set in motion by intrigues that seem to cause the discontinuation of the dynasty. It is the threat of the end of regular kingship that instigates the recapitulation of the principles of sound government. It causes a crisis in which the various roles are reconfirmed.

Finally, the complexity of kingship and the discourse supporting it are reflected in the complexity of the texts. The dialogic nature of kingship is mir-

6 Proclaiming Harmony, 73. 
rored in the dialogic structure of the text, which contains various elements contributing to its dialectic mechanism. The alternation between frame and stories, fictional and historical levels, quoted texts and narration produces an interaction between narrative levels, which enables the juxtaposition of a narrative reality with evocations of the imagination; specific cases with universal principles; the roles of various persons; and the practice of kingship with its underlying assumptions. It is the dialogic mechanism built in the text that indicates its main function, the setting in motion of a process of interpretation that will not only instruct the prince and the reader, but also convince them of the basic ideological principles involved in the institutionalization of authority.

Perhaps the main theme of the cycle of the 'Seven viziers' discussed above is the notion of 'initiation'. In the beginning, the prince is inexperienced and ignorant, even reluctant to learn anything. After his tribulations, he is instructed according to a new method-by imagined representations of knowledge-and is taught everything he needs to know to fulfil his future tasks. This reflects the procedures of the text itself, which also aims to instruct through representations, in the form of exemplary tales, indicating that, ultimately, the narrative is aimed at the reader, who is instructed in the traditional wisdom concerning statecraft. It follows that kingship is not merely connected to specific situations or specific persons; it is part of a much broader framework that stretches into history and into the realms of culture, the imagination, and religion. This is made even clearer in the case of the emperor in Proclaiming harmony, whose fate is linked to the universal configuration of the celestial forces, and the functioning of the systems of government in the divine spheres. In most cases, government is related not only to the framework of tradition, but also to that of religion.

The notion of 'initiation' has the connotation that kingship is a privilege not available to just anyone but is granted only to the chosen ones. This is especially true when there is a strong link between kingship and religion or, more generally, supernatural forces. A nice example of this is the corpus of Indian tales known under the title The twenty-five tales of the genie and The thirty-two steps of the throne. Both narratives, in their various versions, probably have ancient sources but were written down around 1300 and remained popular even until modern times. The cycles revolve around the figure of Vikramaditya, the legendary king who became the centre of a vast array of narrative material. In 
the course of time, he became the prototype of the ideal king and a model for proper kingship sanctioned by God. ${ }^{7}$

The Twenty-five tales of the genie is a framestory in which the legendary beginnings of the kingship of Vikramaditya are related. The story starts with a king who is eager to gain access to the wisdom of a yogi who is meditating in some isolated place. The sage refuses to break his solemn silence, and the king, annoyed, sends a prostitute to seduce him to speak. The ruse is successful, but the sage's disruption of his sacred state sets in motion a sequence of events resulting in one of his sons aspiring to world domination. Another sage asks Prince Vikramaditya to intervene; he should go to a cemetery and carry a corpse hanging from a tree to a yogi who requests his help. But he is not allowed to speak. Vikramaditya obeys, but the corpse appears to be possessed by a genie, who, as soon as Vikramaditya hurls the corpse over his shoulder, begins to tell a story, asking a question in the end. Vikramaditya cannot help but answer the question, whereupon the genie returns to the tree and the cycle starts again. After twenty-five efforts (and twenty-five stories) the genie explains to Vikramaditya that the yogi has evil intentions and instructs him to kill him in a ritual way. After doing so, Vikramaditya receives knowledge of the principles of kingship, which, of course, were already conveyed by the twenty-five tales.

The story in the frame seems to be an allegorical representation of the origins of kingship according to divinely inspired principles. At first a king has power but is refused access to wisdom; then a yogi who possesses knowledge strives for worldly power but is prevented by God. In the end, Vikramaditya succeeds in defeating the anomalous forces by acquiring both worldly power and wisdom, and the blessing of the divine powers. The whole process is imbued with taboos, which are neutralized by ritual acts involving storytelling, death, and revelation. Vikramaditya is initiated into the divine knowledge of the principles and powers of world hegemony during the ritual performance and can assume his role as a king, a warrior, a scholar, a patron of the arts, and, most of all, a man of compassion and self-effacement. He is the ideal king who combines innate capacities with divinely inspired knowledge. The genie, freed from his imprisonment, is appointed as his vizier.

The story of Vikramaditya is picked up in the related cycle of The thirty-two steps to the throne, which is preserved in several versions from the fourteenth to eighteenth centuries. In the framing story, we learn that on a farmland there has

7 Sivadasa, The Five-and-Twenty Tales of the Genie, trans. Chandra Rajan (London etc., 2006); Les trente-deux marches du trône ou comment mériter le pouvoir, trans. Daniel Lescallier (Paris, 2014); Les trente-deux récits du trône (Batris-sinhasan) ou les merveilleux exploits de Vikramaditya, trans. Léon Feer (Paris, 1883). 
been found a throne that could be taken to the royal court only after a solemn ceremony. When the king wants to mount the throne, he is halted by a genie, who tells him that the throne belonged to Vikramaditya, who ascended it after killing a vicious genie. The king, called Bhodja, or Béhoudje, attempts to climb the steps of the throne, but he is prevented from doing so by the genie of the statue on the first step, who tells him an exemplary story about the virtues of kings, especially Vikramaditya. This is repeated thirty-two times, until Bhodja finally succeeds in settling himself on the throne. Here, again, we see a ritual process aimed at instruction and the transformation of a specific person into a king, through the acquisition of knowledge that ultimately derives from divine revelations through the elevated figure of Vikramaditya.

The exemplary tales in the frame of The thirty-two steps of the throne convey the basic virtues of kings. Typically, they relate how Vikramaditya has defeated all kinds of demons and spirits, which harass innocent subjects by putting a spell on them. This conjuring of evil spirits is mostly achieved by some form of self-sacrifice, the king offering to take the place of the victim and thereby releasing him from the curse. In this way, the many virtues required for just and compassionate rule are displayed, turning Vikramaditya into a model for proper kingship to be emulated by future kings. Of course, the ability to subdue supernatural forces of evil is an important source of legitimacy and power. It not only shows that the king is sufficiently powerful to protect his subjects against this kind of threat; it also proves that he has the endorsement of the gods, who reward his righteousness and conformity to the faith with extraordinary powers to eliminate these intruders.

As a rule, in this type of literature, it is the king who enjoys the favours of the divine forces and who is chosen to be initiated into the secrets of kingship. However, in accordance with the composite nature of authority, as explained above, it is often not the king but the vizier who is selected for a special task and initiated into forms of supernatural knowledge and abilities. After all, the vizier has a specific task that transcends the here and now and requires insight into transmitted and revealed forms of knowledge and wisdom. He needs this knowledge in order to confront potential impulsive reactions of the king and relocate situations of crisis into the proper embedment of rationality and wisdom. This is nicely illustrated by the story of 'King Jaliad of Hind, and his son Wirdkhan', mentioned above, where the stupidities of King Wirdkhan are remedied by the brilliant, even supernatural, talents of the young son of vizier Shimas. The boy may not possess any power, but his insight is superior to the king's because he inherited the miraculous gifts of his father.

In the Chinese tradition this pivotal role of the vizier is elaborated in the novel Creation of the gods (sixteenth century), based on historical events and 
popular lore. ${ }^{8}$ Here, the interrelationship of earthly and celestial events is vividly portrayed in an elaborate story based on, again, disastrous events, in this case the collapse of the Shang dynasty in the eleventh century. The story begins when Emperor Zhou, who is in principle talented but leads a lascivious life and conducts the business of state during orgies. One day the king transgresses a sacred boundary by falling in love with the statue of a beautiful divinity. When he subsequently orders an audition of young maidens to be held at the court, to still his awakened desires, one of the girls is invaded by a malicious foxspirit. The stunningly gorgeous fox-girl is selected as the emperor's favourite concubine and soon starts to interfere with state affairs. She persuades the emperor to have loyal ministers executed, to have the empress thrown from a tower, and to have sumptuous palaces built for mere pleasure.

The sudden turn of events and the deterioration of the functioning of the state cause a split in the ranks of officials and notables. The corrupt ministers exploit the situation, while the loyal ministers who are not killed stage a revolt led by a prominent earl. This earl, being able to foresee the future, hands himself in to the emperor and is imprisoned. After seven years he is released and returns to his province to start a revolt against the emperor, which is supported by other provincial lords. The revolt enters a new phase when the sage Jiang Ziya joins the cause of the rebels. Jiang Ziya used to be a good-fornothing unsuited for any trade, until his prognostic gifts are discovered. He is invited to the court of the emperor, but when he receives the assignment to construct a costly palace on impossibly short notice, he flees the capital and settles in the province as a humble fisherman. One day he is discovered as the man who is destined to lead the rebellious troops against the evil emperor.

What follows is an extended account of the expedition of the armies of King $\mathrm{Wu}$, the son of the earl who initiated the revolt, against the imperial army. During the battles the help is invoked of all kinds of sorcerers and knights with miraculous powers, supported by factions in the realms of the gods, demons, and immortals. The war shows how the effectuation of fate is the outcome of a complex struggle in which celestial and earthly forces intermingle and amplify or obstruct each other. In this clash the pivotal figure is Minister Jiang Ziya, who is capable of mobilizing and directing the forces within the various levels of the struggle and who, unlike anyone else, understands its many dimensions. He is not only in touch with the celestial forces through his geomantic talents; he is also able to deploy the divine and cosmic powers to achieve his aims on earth because he is familiar with the networks, rivalries, and alliances in the

8 Creation of the Gods, trans. Gu Zhizhong, 2 vols. (Beijing, 1992). 
realm of the immortals. And, to be sure, he is selected beforehand to realize the inevitable outcome of fate.

In spite of his tremendous power, Jiang Ziya is still bound by his obedience to the king, and the king is formally subservient to the emperor. This is nicely shown in the story after the defeat of Emperor Zhou, when King Wu is invited to take possession of the imperial throne. Even after the chaotic and bloody battles, King Wu prefers to preserve traditional procedures, and to the consternation of all present he declines the honour. Only after repeated requests of all the notables and common subjects is he persuaded to become the new emperor. This reluctance is not merely imposed by modesty or by the historical examples of virtuous emperors; King Wu is portrayed as a mild, even diffident and weak, leader, who is not aware of the significance of events and of his own role. He earns legitimacy through his support for the just cause, his descent, his moderate and compassionate disposition, and through the configuration of the forces of destiny. Jiang Ziya, who holds actual power, derived from his insight and supernatural 'connections', becomes the new prime minister.

The many intrigues and thematic lines in Creation of the gods illustrate the multiform nature of kingship within the Chinese tradition. Kingship can survive only as long as harmony is maintained between the emperor and his ministers. This harmony is secured only by a correct adherence to the procedures and the prescriptions of all parties involved, but it is also inseparable from their moral integrity. The emperor's relapse into immoral and unheedful behaviour fosters disloyalty and corruption among the officials and, subsequently, the disintegration of the empire. Since the king personifies the moral values imposed by the gods, his failure to heed them irreversibly leads to disaster. As in other examples, it is the minister who represents the embedding of the events and the emperor's personal mishaps in the broader frameworks of history, religion, and fate.

One of the interesting aspects of Creation of the gods is the way in which it displays how the dialectic between the emperor and his ministers interacts with kingship as an institution sanctioned by the gods and governed by fate. The outcome of the historic struggle is determined by fate, but it still has to be enacted by all the persons involved. Most of these are not cognizant of the course of fate and have to deal with their own personal destinies and their earthly and, possibly, celestial responsibilities. The emperor is caught in the mechanisms of the fate of his dynasty, but, through his behaviour, he is also the catalyst causing, or at least enabling, fate to impose itself. The example of his downfall can thus serve as a warning for later emperors to preserve their moral impeccability. This tension between fate and moral responsibility is nicely illustrated by the fox-spirit, who, when captured in the end, argues: 'We've done 
our best to ruin the Shang Dynasty. How can you be ungrateful?' The immortal who will punish her answers: 'I sent you to help King Zhou lose his kingdom; it was just as fate had destined. But you were too cruel and ruthless. You murdered so many loyal ministers and innocent people. Your crimes are too great and you must be dealt with according to the law.' ${ }^{\prime 9}$ Apparently, the fox-spirit had been an overly efficient instrument of fate, abusing her limited freedom to act by indulging in her evil inclinations.

The two examples analysed in this section show how the institution of kingship derives part of its legitimacy from religious and cosmic frameworks that impart it with the powers to neutralize evil forces on earth by often miraculous means. The heavenly connection is not only beneficial for practical and ideological reasons; it also emphasizes the ethical component of the institution of kingship, which is reflected in the character and moral attitude of the king. The king personifies a morality to which he himself is bound, but which also radiates from him over the community as a whole: When the king's morality falters, the situation of the empire as a whole is affected. This significant link between the king and the religious-moral framework implies that not everyone is suited for the task. Kings, and often viziers too, are chosen as privileged intermediaries between the earthly and divine realms. The key to this privilege is insight into the secrets of divine wisdom and the revelatory power to shape events on earth according to the divine will.

It has been remarked above that it is among the king's privileges, and sometimes duties, to use violence to impose his authority. This is not restricted to cases of betrayal or disloyalty, but extends to more significant incidences of battle and war. As in other cases of imminent violence, actual bloodshed is preferably avoided, mostly through the intervention of a wise vizier. When it is unavoidable, however, it should be pursued with vigour and determination, to deter real and potential enemies. Still, the conduct of war is not just an outburst of random violence, but rather an undertaking regulated by discipline, hierarchies, rules, customs, and codes, which are necessarily related to the person of the king and the institution of kingship. The enormous impact of war on societies is thus mitigated by structuring mechanisms. On the ideological level, the historic significance of warfare, its connections with kingship, its codes, and

9 Creation of the Gods, vol. 2, 432. 
its implications for societal and communal identification are conveyed mainly within a generic corpus that remained popular in the whole of Eurasia throughout the centuries: the romance of chivalry.

Of course, romances of chivalry, in their epic and more novelistic forms, occur in various types, but in the period and area under study, Eurasia, 1300180o, a remarkable resemblance can be perceived between the various cultural domains. The structure, themes, motifs, narrative strategies, and ideological implications of works such as the Catalan Tirant lo Blanc, the Persian Hamzanama, and the Chinese Yue Fei are surprisingly similar. Although, as in other cases, it is difficult or even impossible to prove historical connections and direct influences, it is not unlikely that they were conceived according to similar patterns and derived from similar cultural and literary visions. In this section we will briefly discuss two examples of chivalric narratives that illustrate attitudes towards kingship and that have remained influential within the literary traditions for a long time: the Catalan romance Tirant lo Blanc and the biographical 'novel' Sirat Baybars, the epic story of the Egyptian Mamluk Sultan al-Zahir Baybars.

The chivalric romance Tirant lo Blanc, written by Juanot Martorell and Joan de Galba and printed for the first time in 149o, marks, on the one hand, the culmination of the chivalric tradition in Europe in a sophisticated and ambitious book and, on the other hand, the end of the cultivation of chivalry and the emergence of new generic types. Although it thus closed off an era, it also remained a model especially for popular romances in the sixteenth century. Its popularity is not unrelated to the conquest of Constantinople by the Ottoman Turks in 1453, which utterly shocked European Christendom and led to a new preoccupation with the Orient. The old forms of orientalism were gradually transformed into new narrative elements within the genres of the romance and, later, the novel. Still, the ancient models of knighthood and chivalric codes, as an institution pervading society, declined into idealized representations of adventure and romance. ${ }^{10}$

The story of Tirant lo Blanc opens with an episode about the adventures of the famous English knight William of Warwick, who, after a pilgrimage to Jerusalem, retires for contemplation in an isolated shed, although he is temporarily called back to the battlefield to repel a Moorish invasion. He isby coincidence-visited by a Breton nobleman, whom he teaches the basic

10 Joanot Martorell and Martí Joan de Galba, Tirant lo Blanc, trans. David H. Rosenthal (London, 1984); see also Joseph Anthony Vaeth, Tirant lo Blanch: A Study of its Authorship, Principal Sources and Historical Setting (Memphis, 2010); and Henry Thomas, Spanish and Portuguese Romances of Chivalry (Cambridge etc., 1920). 
doctrines, codes, and customs of knighthood. Thus instructed, the nobleman, who is Tirant lo Blanc, continues his journey to the English court where all the valiant knights of Europe have gathered for a tournament. Tirant beats all his opponents and is incorporated into the knightly Order of the Garter, founded by the English king. After some preparatory peregrinations, to Rhodes, Jerusalem, Alexandria, and Sicily, Tirant responds to the request from the Byzantine emperor for support against the encroaching Turkish troops. He prepares a ship and departs for Constantinople, where he is immediately appointed as admiral of the Christian army. After a protracted struggle Tirant succeeds in pushing back the Turks and imposing an advantageous peace treaty.

The story of Tirant is partly the personal story of the hero's initiation into the exclusive status of knighthood, which is among the basic institutions structuring society, and his subsequent rise to fame. It is also an evocation of the vicissitudes of a society, even a civilization, confronted with an intimidating foe. It is not only an adventure; it is also an effort to redefine, reinforce, and mobilize communal sensitivities and solidarity, and a mental boost to neutralize the fear of the Ottoman advance. The first point of identification to achieve these goals is the hero's faith. All Tirant's actions, decisions, and thoughts are imbued with loyalty to the Holy Catholic Church, to which he has sworn unflagging support when obtaining the status of knighthood. The decision to undertake the mission to Constantinople was triggered by the news that the Turks were refurbishing the main cathedral in Constantinople as a stable for horses. Religiosity motivates his actions, energizes his efforts, and serves him as a moral guide.

The faith, or more particularly the Catholic Church, is to a large extent identified with Europe, as a socio-political entity. Although the name 'Europe' is not mentioned, it is clear that the defence of Constantinople is seen as a common cause that should unite all the European kingdoms and polities. This is indicated by the description of the various crowns worn by the rulers of Europe: dukes wear a silver crown; counts wear a leather crown; marquises have a steel crown; kings have a golden crown; and the emperor possesses seven golden crowns. The symbolism is clear: all the European rulers are ranked in a hierarchical system, rooted in the institution of knighthood and united under the supreme authority of the Byzantine emperor. As if in a last upsurge of the Crusader spirit, Christianity, with the Byzantine emperor as its historical, symbolic head, should be mobilized to confront the Muslim Turks. This vision is strengthened by a remarkable inserted passage in which King Arthur is staged as the legendary patriarch of Christian chivalry.

In the dualistic configuration of authority centred around the emperor and the knight, the components of power are evenly distributed. The emperor 
possesses various forms of legitimacy derived from his dynastic descent, his position as head of the Church, and the symbolic prestige accumulated in his person through history. Nevertheless, his actual power has diminished, the vitality of the empire has dissipated, and new, strong enemies have emerged. The weakness of the emperor requires a reinvigoration in the form of an energetic force, represented by the hero, Tirant. However, the hero does not merely add the elements of power and vitality to the fragile imperial structure; he also embodies its moral values and its cultural identification as a paragon of piety, justice, courage, ingenuity, and stamina. He is therefore the character with whom the audience can and should identify and who fills symbolic power with real power, without, however, relinquishing his loyalty to his ruler. He has no inclination to bring the emperor down and usurp the throne, but rather faultlessly fulfils his role within the hierarchy. Ideally, the hero would marry the princess and their son would inherit the throne, ushering in a new era of imperial rule. In the case of Tirant, this outcome is nearly achieved.

The pattern of Tirant is both thematically and structurally mirrored in the famous epic of Amir Hamza, the Hamzanama, which has remained popular in Persian, Urdu, and Arabic versions from at least the sixteenth century until the present day. ${ }^{11}$ Here the weakened emperor is the Sassanid ruler Anushervan II, whose throne is shaking as a result of external enemies and internal discord. The dynasty is saved by the intrepid warrior Hamza, the son of 'Abd alMuttalib, the paternal uncle of the Prophet Muhammad. Even before Muhammad is born, Hamza starts spreading the new faith. He defeats the enemies of Anushervan and offers him his services, subduing refractory rulers throughout the empire, and all the while courting the emperor's daughter. Although he is soon the most powerful man in the empire, he remains loyal to the emperor and refrains from appropriating the throne. He is satisfied with urging Anushervan to convert to Islam, adding the historical legitimacy of his dynasty to the vitality and vigour of the new faith.

This pattern of the construction of authority, of course, rests on a specific vision of kingship as being rooted in history and filled with sufficient moral symbolism as to retain its legitimacy. The pattern changes when the figures of the hero and the king converge into one character and the ruler cannot boast historical credentials and rather has to acquire legitimacy through his deeds and disposition. This is illustrated by the figure of the Mamluk Sultan al-Zahir Baybars (1223?-77), the hero of the Sirat Baybars, which probably originated in

11 Ghalib Lakhnavi and Abdullah Bilgrami, The Adventures of Amir Hamza, trans. Musharraf Ali Farooqi (New York, 2007). 
the sixteenth century as a compilation of narrative material from the popular literary tradition..$^{12}$ The backbone of the story is the rise to power of the lad Mahmud, who is bought as a slave by the Ayyubid Sultan al-Salih Ayyub and who steadily increases his power in the ranks of the Mamluk amirs to become the founder of the Mamluk sultanate in Egypt and Syria. His heroic exploits were especially directed against the invasions of the Crusaders from the West and of the Mongols from the east.

The main difficulty underlying the thematic intrigues of the narrative is that Baybars was a stranger in the empire he was destined to rule. Although of noble descent, he was torn from his family in Central Asia and arrived as an 'orphan' in Damascus. In this rather desperate situation, he received the first signs of his illustrious future in the form of the prophecy that someday he will be king of Egypt, Syria, and the 'Islamic land'. This prophecy is confirmed by his acquisition of a huge mace that, according to an old book, came from Samarkand and was predestined to be bought by a future king. After he has settled in Cairo, as one of the Mamluks of Sultan al-Salih Ayyub, he gradually rises within the ranks of the Mamluk amirs, taking up administrative posts and distinguishing himself on the battlefield. Moreover, he shows compassion towards the common people, especially women, and even behaves correctly towards the hostile, treacherous Franks and the idolatrous Mongols.

Throughout this account, the ambiguity of Baybars's identity is upheld. During an expedition against the Mongol-Persian Khan Halawoun (the historical Hülegü), he is tempted to go over to the enemy, reflecting: 'I want to go to the Persians; I was born a Persian. ${ }^{13}$ It is repeatedly hinted that Baybars's Arabic is deficient, and it is significant that he marries a Mongol princess, promising to

12 Roman de Bä̈bars, vol. 1: Les enfances de Bä̈bars, trans. Georges Bohas and Jean-Patrick Guillaume (Paris, 1985); vol. 2: Fleur des Truands, trans. Georges Bohas and Jean-Patrick Guillaume (Paris, 1986); vol. 3: Les bas-fonds du Caire, trans. Georges Bohas and JeanPatrick Guillaume (Paris, 1986); vol. 4: Le chevauchée des fils d'Ismaïl, trans. Georges Bohas and Jean-Patrick Guillaume (Paris, 1987); vol. 5: La trahison des émirs, trans. Georges Bohas and Jean-Patrick Guillaume (Paris, 1989); vol. 6: Meurtre au hammam, trans. Georges Bohas and Jean-Patrick Guillaume (Paris, 199o); vol. 7: Rempart des Pucelles, trans. Georges Bohas and Jean-Patrick Guillaume (Paris, 1992); vol. 8: La revanche du maître des ruses, trans. Georges Bohas and Jean-Patrick Guillaume (Paris, 1996); vol. 9: Échec au roi de Rome, trans. Georges Bohas and Jean-Patrick Guillaume (Paris, 1997); vol. 10: Le procès du moine maudit, trans. Georges Bohas and Jean-Patrick Guillaume (Paris, 1998); see also: Jean-Claude Garcin, ed., Lectures du Roman de Baybars (Marseille, 2003); Thomas Herzog, Geschichte und Imaginaire: Entstehung, Überlieferung und Bedeutung der Sirat Baibars in ihrem sozio-politischen Kontext. Diskurse der Arabistik, vol. 8 (Wiesbaden, 20o6). 
remain monogamous. The link with the subjects of the empire is established, apart from his compassionate image, by the figure of Uthman, who becomes his loyal lieutenant and cherished friend. Uthman is a notorious rogue of outstanding good looks, who is rough, uneducated, and impulsive, but extremely loyal and ingenious in all his uncouthness. Baybars teaches him discipline and obedience, and the basics of the faith, promising him some personal privileges. Throughout the story, Uthman is presented as a man of the people, speaking in Egyptian dialect and figuring in many farcical episodes taken from popular lore. He is Baybars's alter ego, embedding him in the imagination of the community.

A second set of episodes fostering Baybars's affinity with his subjects concerns religion. It is stressed that even as a child, Baybars was proficient in the religious sciences, and he is consistently presented as a champion of the Muslim faith. This religiosity is supplemented by an evident moral attitude, in contrast to the religious scholars in Cairo, who are always scheming against him and pursuing their material desires. This straightforward 'official' and practical piety is extended to encompass several elements of what is usually called 'popular' belief. Baybars is an admirer of Sayyida Zaynab, the patron saint of Cairo; he has a meeting with the mysterious saint al-Khadir (al-Khidr) who teaches him the art and codes of war; and he is summoned before the prominent popular saint Ahmad al-Badawi, whose tomb is the centre of pilgrimage in Tanta and who provides Baybars with new prophecies and a magic ring. All these events seem to serve as compensation for Baybars's lack of ethnic affiliation and to present him as a hero of the people who has earned the right to become their ruler.

Although events seem to conspire to facilitate Baybars's ascendancy, it also requires his personal assets, such as his political acumen, his courage, and his compassionate nature. Here we see the tensions similar to those inherent in the Chinese kingship mentioned above, a predestined kingship that obtains its legitimacy from the religious framework but is also realized by the personal character and endeavours of the hero. Baybars's kingship is not inherited but established; it is not an institution continued within a sacred, dynastic tradition, but built by a combination of personal effort, skill, and divine will. This set of factors is especially relevant for the Central Asian and Turkish and Persian rulers who came to power in the late Middle Ages and early modernity, such as Timur Lang, the Persian Ilkhans, the Safavids, the Mughals, and the Ottomans, who had to construct states themselves and had to find legitimations for their claims in the Islamic tradition, in popular religiosity, and in the tradition of Central Asian statecraft. ${ }^{14}$ 
The main constituent framework of the narratives discussed in this section is history, and it is safe to surmise that they have served as part of a discourse about the historical embedding of concepts of kingship. They contain explicit historical references, which are mostly used to prove the historical roots of the dynasty, the cultural and ethnic coherence of the community as it emerged in history, and sometimes the myth of origin of a community or an empire. As such they certainly reflect official discourses of power, especially since they usually endorse historical and political stability and provide legitimacy to dynastic claims. However, the stories all contain important elements taken from popular literature and combine historical references with clear extravagances and indulgence in the imagination. They can therefore be seen as a medium between the various layers of the discourse of power, incorporating structures of power into the collective imagination.

Apart from this direct ideological function, the romances can also be perceived as reservoirs of the cultural tradition, in which not only social and cultural identifications were preserved and transmitted, but also a coherent corpus of moral values, exemplary behaviour, and just rule. Through these narratives cultural and moral self-images were stored in socio-cultural domains that were not directly dependent on political systems and structures. Here we encounter an intriguing complexity in this kind of narrative material: history was their natural 'milieu', and they bear the traces of historical change, whereas they also have a tendency to transcend historical phases and were perhaps even intended as a repository of the moral and symbolic capital accumulated within historical trajectories. For kings and dynasties, the concepts conveyed by this literature were of tremendous value for transforming their power into a durable form of authority.

Even a superficial glance at the narratives analysed so far creates the impression that one of the main characteristics of literature about kingship was its persistent misogyny. Women do not rule; they rather disrupt the survival of dynasties by their unruly interference and unleash forces that lead to the ruin or imminent collapse of empires. This destructive influence is systematically related to capacities considered as typically female, such as irrationality, sensuality, per-

2014); Ron Sela, The Legendary Biographies of Tamerlane: Islam and Heroic Apocrypha in Central Asia (Cambridge etc., 2011). 
fidy, and emotionality. It would seem that the general discourse proclaims the essential incompatibility of femininity and statecraft. Proper governance and the stability of the state require the marginalization of women and their exclusion from state affairs. However, a close look reveals that the situation is more complex. Women are perhaps a threat to the very survival of the empire; their contribution is also indispensable for the survival of the dynasty. This is the dilemma inherent in dynastic politics and discourses expressed in our narratives of kingship, which may be called the feminine paradox: women are both a curse and a blessing, a necessity for and a threat to the preservation of kingship.

Although misogyny is a ubiquitous phenomenon, not all narratives discussed above have only negative roles for women. In the romances of chivalry, women are often objects of desire for the hero, to be served, revered, protected, and loved. In Tirant lo Blanc, the story of the struggle against the Turks is interwoven with the hero's courtship of the gorgeous Byzantine princess Carmesina, and the couple often take the time to dispute about all aspects of love. In the end, probably for narrative reasons, the union of the two lovers is precluded by Tirant's untimely death. Likewise, Hamza for the duration of the story tries to conquer the princess Mehr-nigar, like Carmesina the sole child of the emperor. These women represent the positive aspects of femininity; they are beautiful, they personify dynastic legitimacy, they respond to the energetic preoccupations of the hero, and they provide a parallel storyline to the recurrent battles, as an alternative prize for the hero's perseverance. War and love are the quintessential elements of adventure and of the survival of dynasties.

This positive view of women is more prominent in another type of kingship narrative, the love romance, which was popular in all Eurasian traditions alongside the romance of chivalry and (historical) novels. In Europe, a genre of romantic novels emerged in the seventeenth and eighteenth centuries, which contained traces and strategies of the medieval and early modern romances, including their exotic excursions, while in China the theme of love remained crucial in the portrayals of kingship and social critique. In the Islamic realm, we find a large corpus of romances that appear to be somehow related to each other, stretching from late medieval Persia to sixteenth-seventeenth-century India, Mamluk Egypt, and the Ottoman Empire. In this section we will discuss a cluster of these love romances that transcend linguistic, political, and, to some extent, cultural boundaries to reveal a rich spectrum of literary and ideological concepts. Although we lack sufficient information to establish philological relationships between the various narratives, their connectedness is evident. Perhaps the stories originated in Persia and spread from there to the 
East and, later, to the Arabic/Ottoman realm and, to be sure, from there to Europe in the translations of the Thousand and one nights and similar Oriental sources. ${ }^{15}$

The cluster of stories that we will discuss here consists of the various versions of the romances of 'Sayf al-Muluk and Badi al-Jamal' and 'Janshah', all incorporated into the later versions of the Thousand and one nights, and the love/Sufi romances 'Mirigavati' by the Hindavi poet Qutban Suhravardi (1503). Of course, there is not enough space here to elaborately analyse these texts. We will concentrate on aspects related to the connection between women, kingship, and love. ${ }^{16}$

As in several narratives analysed above, the story of 'Mirigavati' begins with a prophecy, saying that a new-born prince, Raj Kunvar, will suffer grief because of a woman. When he has reached his adolescence and sets out for a hunting excursion, he perceives a fleeing doe. He follows her, but she disappears into a lake. He builds a palace on the bank and sometime later sees a group of gorgeous nymphs playing in the water. He falls in love with one of them and captures her by stealing her sari, but soon she escapes and flies away, summoning him to follow her to the City of Gold. Then Ray Kunvar's adventure begins: he dresses as a yogi and sets out to find his beloved. After long and dangerous peregrinations, he is washed ashore on an island where a lovely princess is held captive by a demon. He kills the demon and continues his journey, reaching the City of Gold after many miraculous mishaps and escapes. The two lovers finally consummate their union and seal their marriage. On the way home, Raj Kunvar picks up his earlier spouse, and they settle in his palace. One day he goes out hunting and is killed by a tiger; his two wives follow him into death according to custom.

The various episodes and motifs in 'Mirigavati' closely resemble the stories of 'Janshah' and 'Sayf al-Muluk'. A peculiar complication at the end of the story of both 'Mirigavati' and 'Sayf al-Muluk' is that the result of the prince's search is not the realization of a true, romantic love, but his possession of two wives. In 'Sayf al-Muluk' this is adroitly, but somewhat artificially, solved by the sud-

15 Thomas, Spanish and Portuguese Romances of Chivalry; for the reception of the Thousand and one nights in Europe and orientalism, see: Pierre Martino, L'Orient dans la littérature Francaise au XVIIe au XVIIIe siècle (Paris, 1906); Srinivas Aravamudan, Enlightenment Orientalism: Resisting the Rise of the Novel (Chicago and London, 2012); Martha Pike Conant, The Oriental Tale in England (New York, 1966); Marzolph and van Leeuwen, Arabian Nights Encyclopedia.

16 The Arabian Nights, vol. 2, vol. 3; Qutban Suhravardi, The Magic Doe: Qutban Suhravardi's Mirigavati, trans. Aditya Behl (Oxford, 2012). 
den appearance of the prince's foster-brother, who can marry the superfluous princess. In 'Mirigavati' the problem is not very satisfactorily solved by the death of all protagonists. According to Aditya Behl, who translated and analysed the romance, the two wives should be interpreted as symbolizing two different levels of reality. The first princess represents earthly desires and preoccupations, easily fulfilled but not the ultimate aim of the quest, whereas Mirigavati, in contrast, personifies the divine and spiritual realm, which requires a higher level of consciousness and achievement. Only after realizing the amalgamation with this second, more elevated, realm, has the prince accomplished his search and can he be established as a king.

The notion of the spiritual dimension embodied by Mirigavati is connected with the concept of rasa, which, in the Indian tradition, refers to the aesthetic harmony when perfect (poetic and physical) beauty, sophistication, sensuality, and emotional satisfaction converge. It is only when the sense of rasa is achieved, with the union and lovemaking of the beloveds, that their love is accepted as true and that the perfection of the prince as a lover and as a ruler is proven. The concept of rasa is also mentioned by the princess as the reason for her escape: Since Raj Kunvar had captured her by using violence, the required harmony was lacking in their relationship, and the prince still had to prove his merits and suitability. It is here that the constitutional elements of kingship are evinced, Raj Kunvar proving his courage and perseverance, apart from his outstanding abilities as a man and a lover. This perfection, making him the ideal king, can be attained only through the union with an equally elevated, even semi-divine, spouse.

The idea of rasa is the cornerstone for an understanding of the story of 'Mirigavati'. It is therefore remarkable that it is absent in the Arabic story of 'Janshah', which also contains the episode of the captured jinn-princess fleeing to faraway lands. Here the escape of the princess is not explained, and the connotation of harmony is lacking. This is perhaps the reason why the jinn-princess is tragically killed by a shark after her reunion with Janshah, apparently arguing that a harmonious union between a human prince and a jinniyya is improbable and perhaps even inappropriate. This omission, possibly due to an 'Islamization' of the story, not only makes the story less consistent; it also deprives it of its spiritual purport. In 'Janshah' and 'Sayf al-Muluk' the journey to the beloveds is not a trajectory of spiritual elevation, but rather a journey through the realm governed by Sulayman (Solomon) and his helpers, a kind of underworld where the forces of nature are visible and where all kinds of monsters and demons have their abode. It is thus rather a quest for knowledge than a quest for insight, rather a journey of exploration than a journey of spiritual perfection. 
The three romances of 'Mirigavati', 'Janshah', and 'Sayf al-Muluk' nicely demonstrate several aspects of kingship as conceived in the Indian-Islamic realm. The stories commence with a rupture, or the threat of the end of the dynasty. The prince, before he can succeed his father, has to be initiated into the secrets of life, and, more concretely, into the obstacles on his way to fulfilment, into knowledge of the hidden layers of reality, and, of course, into the experience of true love. He enters a phase of liminality in which he is cast back into the state of an individual striving for survival and the conquest of the object of his desire, temporarily suspending the tight framework of social conventions and dynastic constraints. The aim of his quest is a queen who will not only secure the continuation of the dynasty, but also complement him as a human being and as the centre of the institution of kingship. Through her the young king has proven his capability, his legitimacy, and the aesthetic perfection of his authority. Although the love for a woman endangered the very survival of the dynasty, her recuperation has made kingship, as an institution, stronger and more vigorous than before.

Interpreted in this way, the romances present a positive turn to the dilemmas posed by the more misogynist narratives discussed above. They show how narratives of kingship are perhaps patriarchal and tend to marginalize women, but also acknowledge the necessity of involving women in the reproduction of power and authority. Paradoxically, the discourse of power excluding women, being designed to exclude them, presupposes their presence and makes sense only if it incorporates their presence in its construction. This paradox perpetually implies the possibility, the probability, and even inevitability of their intervention. The complications of this seemingly contradictory situation are ingeniously elaborated in the epistolary novel Lettres persanes by the French philosopher and writer Montesquieu (published in 1721). Although it is not a novel about kingship strictly speaking, the work does comment on discourses of power and the implications of gender roles for the exertion of authority. It is simultaneously a critique of French society and an evaluation of what is usually called 'Oriental despotism.' ${ }^{17}$

Montesquieu's novel Lettres persanes fits into several trends that converged in French literature at the beginning of the eighteenth century. First, it illustrates the tendency, in the seventeenth and eighteenth centuries, to experiment with more complex narrative forms, marking the transition from the relatively straightforward genre of the romance to more layered novelistic literary strategies. Two trends were particularly influential in this development: the popu- 
larity of the epistolary novel, showing a more fragmented narrative technique; and the appearance of the French translation of the Thousand and one nights made by Antoine Galland and published from 1704 to 1717, with its composite structure. Second, it continues the interest in the Orient as a narrative element, after the example of the romances, but it has now been enriched by the increasing direct interaction with Oriental societies, resulting in more 'realistic' knowledge; the Oriental motifs are used not as a romantic, exotic excursion, but rather as a mirror for French and European society, spawning self-reflexivity and social critique. Moreover, after Galland's translation, forms of orientalism were not only derived from imagined or experienced Orients, but also from the literary characteristics of the Thousand and one nights. ${ }^{18}$

These characteristics of Lettres persanes not only marked a new phase in European literature, leading to the 'invention' of the modern novel; they also indicate a differentiation within the Eurasian literary traditions. Whereas in the previous sections we discussed works from different traditions, which nevertheless showed remarkable similarities, we now perceive a clear divergence between the European and Asian traditions. While in the Asian traditions, perhaps with the exception of China, the traditional genres remained popular and were further developed, in Europe new genres emerged inspired by new visions of the world. Perhaps paradoxically, the new trends were to a large extent shaped by the incorporation and emulation of Oriental literary models, such as the Thousand and one nights and similar works. It was especially the Ottoman Empire that provided the link in this trajectory of transmission, connecting its Central Asian heritage and its incorporation of the Arabic tradition with its new European counterparts.

The novel Lettres persanes is built around the intrigue triggered by the juxtaposition of an all-powerful Oriental nobleman with his harem wives, who are subjected to his authority but in the end revolt against it. The main character is Usbek, who leaves his mansion in Persia to travel to Europe to familiarize himself with European culture. He is in touch with his home through letters to his wives and concubines, and to the chief eunuch Ibben. A third correspondent is Rida, who is also on a journey through Europe. The main storylines are, on the one hand, Usbek and Rida's observations about Europe and their travel experiences and, on the other hand, Usbek's relationship with his women at home, especially his most recent wife Roxane. The novel is thus both a critique of 'Oriental despotism' and of 'Occidental despotism', in the appearance of the French king. 
At first Usbek stresses his strong relationship with his wives through the dual bond of love and authority. He praises his wives as the most beautiful women in the world, but also emphasizes their obligation to obey him. This structure of authority appears to be difficult to uphold when the master of the household is absent; the chief eunuch, Ibben, who has the assignment to replace his master's authority, is unable to preserve discipline in the harem, in part because of his emasculated and mentally impotent condition: the women refuse to accept his authority by proxy. Because of his crippled condition, his response to the unruly behaviour of the women is excessively harsh, and before long the dissatisfaction turns into open revolt. The women complain to Usbek about the measures of the eunuch, while Ibben accuses the women of adultery. In the end, it is Roxane, Usbek's favourite wife, who seals the revolt with a letter in which she confesses her infidelity and concedes that she has turned his 'horrible' palace into a place of pleasure and desire. She asks him how he could have thought that she could exist only for his whims and subdue her own desires. She was unable to live in servitude and reformed his laws to conform to the laws of nature. It was only in appearance that she subjected herself to his fantasy, and she has always kept an independent spirit. Now, to show her independence, she has taken poison and is dying, while writing the letter with her last remaining strength.

In the two storylines of the novel we can perceive some familiar motifs. First, we have a 'prince' who sets out on a trajectory to enrich his knowledge of the world, to be initiated in the secrets of Europe, and to complete a trajectory of personal fulfilment; second, we find the composite nature of authority, unveiled by the master's absence and articulated by the figure of the chief eunuch; third, the dilemmas of authority are negotiated through dialogue, here in the form of an exchange of letters; and fourth, there is tension between the institutional and personal aspects of authority, between the prince's male prerogatives as master of the household, between love and power, violence and seduction; and finally, of course, we encounter the motif of the female voice interfering in the structure and enforcement of power, as a marginalized but still powerful influence.

Montesquieu's conceptualization of Usbek's authority seems to indicate that it is a system based on religion and tradition only, an 'unnatural' system since it systematically suppresses women and their desires. This is not problematic as long as Usbek is present and able to combine his personal and institutional roles, but after his departure the emotional component is removed and a cruel, formalized regime remains. Being handicapped, Ibben is unable to substitute his authority for Usbek's, and the women use their typically feminine assets to undermine the over-rationalized system of power: they commit adultery and 
fail to obey the rules of their submission. In a wider context, the destabilization of the structure of authority is caused at least partly by external forces, particularly the growing differentiation between a stagnant Orient and Europe, which is involved in a process of transformation. It is ultimately Usbek's urge to go out on a quest that disturbs the balance of forces of his authority at home.

In the narratives analysed in this section, we find the two aspects of femininity and love in narratives of kingship, as a disruptive force and as a source of continuity and equilibrium. And in both texts we re-encounter many of the literary strategies discussed in the previous sections. The love romances from the Islamic realm start from an imminent disruption of the dynasty because the prince is at a marriageable age and has to overcome many difficulties to conquer his beloved and secure the continuity of the dynastic line. This was also observed in the romances of chivalry discussed above. In Montesquieu's novel Lettres persanes, the role of women is reminiscent of the ancient misogynist cycle of the 'Seven viziers': women are marginalized from the discourse of power, even excluded from power and reduced to objects of desire. Their intervention or rebellion results in an imminent collapse of the system of authority and the relapse into naked violence.

The two narratives also exemplify the ways in which women are part of discourses of authority. As remarked above, these discourses are essentially patriarchal and tend to exclude women. However, by being excluded, women become an integral part of these discourses, and their intervention immediately touches upon their internal logic. In both types of narrative the necessity to include women in the process of dynastic reproduction leads to a critical situation seemingly threatening the very survival of the empire. To counter this crisis, the basic elements of the discourse of kingship are unravelled, re-examined, recapitulated, and, hopefully, restored. This is achieved either by a process of transition of the prince, going through a phase of liminality and education, before he can ascend the throne or by the investigation of the conflict and the disciplining of women, also connected with the education of the prince. In all cases, feminine stereotypes such as infidelity, sensuality, and irrationality are evoked, but they have different meanings: in the romances they are disruptive values but ones required to endow kingship with an indispensable aesthetic component in the form of love; in the conflictual cycles they are overruled by a regime based on rationality, male dominance, and traditional principles. Only in the case of Lettres persanes order is not restored: the implosion of the power system is complete when Usbek's favourite wife commits suicide, destroying all legitimacy of the discourse of authority. 


\section{Concluding Remarks}

In this chapter we have examined discourses of kingship from the perspective of literary, fictional texts. A selected number of texts from the different Eurasian traditions have been analysed that together exemplify the main elements of these discourses and their narratological embeddedness. The texts were selected on the criteria of their generic hybridity and location in between courtly and popular levels, so as to give a picture of the mechanism of linking discourses of power to broader segments of society, anchoring ideological premises in the collective imagination. Significantly, all texts illustrate the fluidity of narratives of this kind, since they can in some cases be seen as confluences of narrative material over long stretches of time, serving as a kind of repository of self-images and shared values of societies. In other cases they clearly show their thematic relationships to texts from other domains. In both cases, they defy cultural and political boundaries and seem to belong to zones of cultural exchange and transmission.

The themes investigated here were, first, the composite nature of kingship, presented as the dialogic relationship between the king and other participants in the structure of authority, such as viziers, warriors, and women. This dialogism seems to be an omnipresent feature: There is no notion of a monolithic form of kingship totally amalgamating the personal and institutional elements of the king's role. Second, kingship is commonly related to processes of initiation, either through the education of the prince/vizier or through some divine revelation or epiphany, linking the institution of kingship to the higher framework of religion and supernatural forces through the figure of the king or the vizier. This is often realized through phases of liminality and ritual processes, through trajectories of travel, or the conjuring of anomalous situations. Third, narratives of kingship are embedded in perceptions of history, both as a source of legitimacy and as a representation of cultural and ethnic identity or collective values. Finally, women play a crucial role in the construction and deconstruction of narratives of kingship, albeit often in the role of the excluded 'other'. Their presence is often a catalyst for the narrative intrigue introducing the explication of the discursive premises underlying discourses of kingship and thereby reconfirming their principles and their position within them. Their role is either disruptive or stabilizing, in both cases intimately connected with the liminal phase in the education of the prince.

These thematic aspects are in most cases woven into the narrative form and strategy of the text, staging women as the breakers of silence, necessitating the explanation of discourses of authority, or constructing forms of postponement through the difficult pursuit of love, taboos and temporal frames, dialogic struc- 
tures, generic hybridity, etc. It is this convergence of thematic contents and narrative strategy that makes these texts so effective: they are about the instilling of discourses of power in fictional characters, simultaneously instilling them in the reader as well. It is also this convergence that suggests relationships between the various cultural and political realms in which these narratives emerge, as if the resemblances can be explained only by processes of influencing and cross-cultural transmission. However, in most cases we lack the historical frameworks to prove processes of interaction and any conclusion on questions such as these would be highly speculative. And it is the intention of this chapter to look for patterns inside an admittedly varied corpus of texts, rather than situate discourses in their historical contexts.

To conclude, the narratives discussed here show that there is a difference between power and authority, the first being based on the immediate threat of the use of violence, within a regime of naked intimidation, and the second incorporated in ideological and aesthetic narratives that emphasize the embedding of power in frameworks of tradition, wisdom, rationality, and human dialogue. Whereas in the previous chapters the historical contexts for the formation of authority have been summarized, this chapter has attempted to fill the gap between the mechanisms described there and the collective imagination, which had to find links with the configurations of power. Of course, the fictional texts discussed here were to a large extent shaped by courtly perspectives, but they also reveal a sense of justice, proper governance, and historical legitimacy that transcends specific political manifestations of power and reflects the moral values connected to visions of proper rule. 